\title{
Taxonomic status of the family Biokoviellidae Mršić, 1992 (Diplopoda, Chordeumatida): reconsideration, with a description of one new species
}

\author{
Dragan Ž. ANTIĆ ${ }^{1, *}$, Tvrtko DRAŽINA ${ }^{2,3}$, Tonći RAĐA ${ }^{4}$, \\ Luka R. LUČIĆ ${ }^{5} \&$ Slobodan E. MAKAROV ${ }^{6}$ \\ 1,5,6 Institute of Zoology, University of Belgrade - Faculty of Biology, \\ Studentski trg 3, 11000 Belgrade, Serbia. \\ ${ }^{2}$ Division of Zoology, Department of Biology, Faculty of Science, University of Zagreb, \\ Rooseveltov trg 6, 10000 Zagreb, Croatia. \\ ${ }^{3}$ Croatian Biospeleological Society, Demetrova 1, 10000 Zagreb, Croatia. \\ ${ }^{4}$ Speleological Society “Špiljar”, 21000 Split, Croatia. \\ ${ }^{*}$ Corresponding author: dragan.antic@bio.bg.ac.rs \\ 2,3 Email: tdrazina@gmail.com \\ ${ }^{4}$ Email: tonci.radja@gmail.com \\ ${ }^{5}$ Email: luka@bio.bg.ac.rs \\ ${ }^{6}$ Email: slobodan@bio.bg.ac.rs

\footnotetext{
${ }^{1}$ urn:1sid:zoobank.org:author:A3774DC0-0710-4F91-8F36-F18620D694E0

2,3 urn:lsid:zoobank.org:author:47C87F36-806F-4F6C-950D-C9E1D48CC747

${ }^{4}$ urn:1sid:zoobank.org:author:06AB80C6-0EBA-4201-96A1-3BA64EE3F717

${ }^{5}$ urn:lsid:zoobank.org:author:D5F49D5B-6BCC-42B4-A000-BE23920C811F

${ }^{6}$ urn:1sid:zoobank.org:author:D2745110-BE94-4FBF-9D36-5ACC9045B3C3
}

\begin{abstract}
A new troglobitic species of the previously monotypic genus Biokoviella Mršić, 1992, B. mosorensis Antić \& Dražina sp. nov., is described from caves on Mt. Mosor, Croatia. In addition to this, B. mauriesi Mršić, 1992, is partially re-described, and the taxonomic status of the family Biokoviellidae is re-considered. The genus Biokoviella is placed in the subfamily Biokoviellinae Mršić, 1992 stat. nov. within the family Anthogonidae Ribaut, 1913. The relationship of the genus Biokoviella with other anthogonids is briefly discussed, and a distribution map of the genus is presented. Notes on ecology and coinhabitants of the genus Biokoviella, and new data on some Balkan anthogonids are also included in the paper.
\end{abstract}

Keywords. Biokoviella, new species, caves, Croatia, Balkan Peninsula.

Antić D.Ž., Dražina T., Rađa T., Lučić L.R. \& Makarov S.E. 2016. Taxonomic status of the family Biokoviellidae Mršić, 1992 (Diplopoda, Chordeumatida): reconsideration, with a description of one new species. European Journal of Taxonomy 205: 1-23. http://dx.doi.org/10.5852/ejt.2016.205 


\section{Introduction}

A little more than two decades ago, Mršić (1992) described the new monotypic genus Biokoviella Mršić, 1992 from caves on Mt. Biokovo in Croatia. For this taxon, he established the new monotypic family Biokoviellidae, indicated similarities with representatives of the families Chamaesomatidae and Anthogonidae, and placed the new family in the superfamily Cleidogonoidea sensu Mauriès (1982). He retained this opinion in his paper from 1994 (Mršić 1994: 249). After that, in Shear's paper from 2000 on the higher classification of Chordeumatida, the family Biokoviellidae was not assigned to any superfamily, not being mentioned at all; however, it was included by Shelley et al. (2000) and Shelley (2002) in the superfamily Cleidogonoidea sensu Shear (2000), a somewhat extended superfamily concept based on Hoffman's classification from 1980, but significantly different from that of Mauriès (1982). The indicated classification of Cleidogonoidea as given by Shelley (2002) was followed by Shear (2011). In Chapter 16 of a recently published taxonomic overview of Diplopoda by Enghoff et al. (2015), the family Biokoviellidae is likewise placed in the superfamily Cleidogonoidea sensu Shear (2000) and Shelley (2002).

In our opinion, great similarities exist between some of the representatives of the family Anthogonidae sensu Antić et al. (2015) and the family Biokoviellidae (see Discussion). After examining a topotype male of B. mauriesi Mršić, 1992, as well as a new Biokoviella species, we conclude that the family Biokoviellidae deserves subfamily level only, and at the family level we synonymize this taxon with the family Anthogonidae. In this rearrangement, the family Anthogonidae should be placed in the superfamily Anthroleucosomatoidea, together with Anthroleucosomatidae and Vandeleumatidae according to Enghoff et al. (2015). These authors included the family Acherosomatidae, together with Anthroleucosomatidae and Vandeleumatidae, in Anthroleucosomatoidea. This chapter was probably prepared before publication of the paper by Antic et al. (2015), where we included the subfamily Acherosomatinae in the family Anthogonidae. In the present paper, we describe one new Biokoviella species from Mt. Mosor in Croatia.

\section{Materials and methods}

Specimens preserved in 70\% ethanol were examined under a Carl Zeiss Jena Technival 2 binocular stereo microscope and a Carl Zeiss Stemi 2000-c binocular stereo microscope with an AxioCamMRc camera. All taxonomically important structures were dissected and mounted in glycerin for temporary microscope preparations and observed under a Carl Zeiss Axioscope 40 microscope. Drawings of gonopods were executed using a computer monitor and pictures made with a Canon PowerShot A80 digital camera connected to an Axioscope 40 microscope. Some relevant structures were investigated with a JEOL JSM-6460LV scanning electron microscope (University Center for Electron Microscopy, Department of Biology and Ecology, University of Novi Sad, Serbia).

The distribution map was created using QGIS version 2.12.0 and Adobe Photoshop CS6. The final images were processed with Adobe Photoshop CS6. The coordinates given in the location data are based on WGS84.

Descriptions of the new species follow a pattern proposed for Chordeumatida by Spelda (2001). The terminology used to denote the different parts of gonopods follows the pattern proposed by Mršić (1992), with some modifications.

\section{Abbreviations for morphological terms used in descriptions}

$\mathrm{a}=$ anterior coxal process

$\mathrm{a} 1, \mathrm{a} 2=$ branches of anterior coxal process

$\mathrm{b}=$ bristle apparatus 


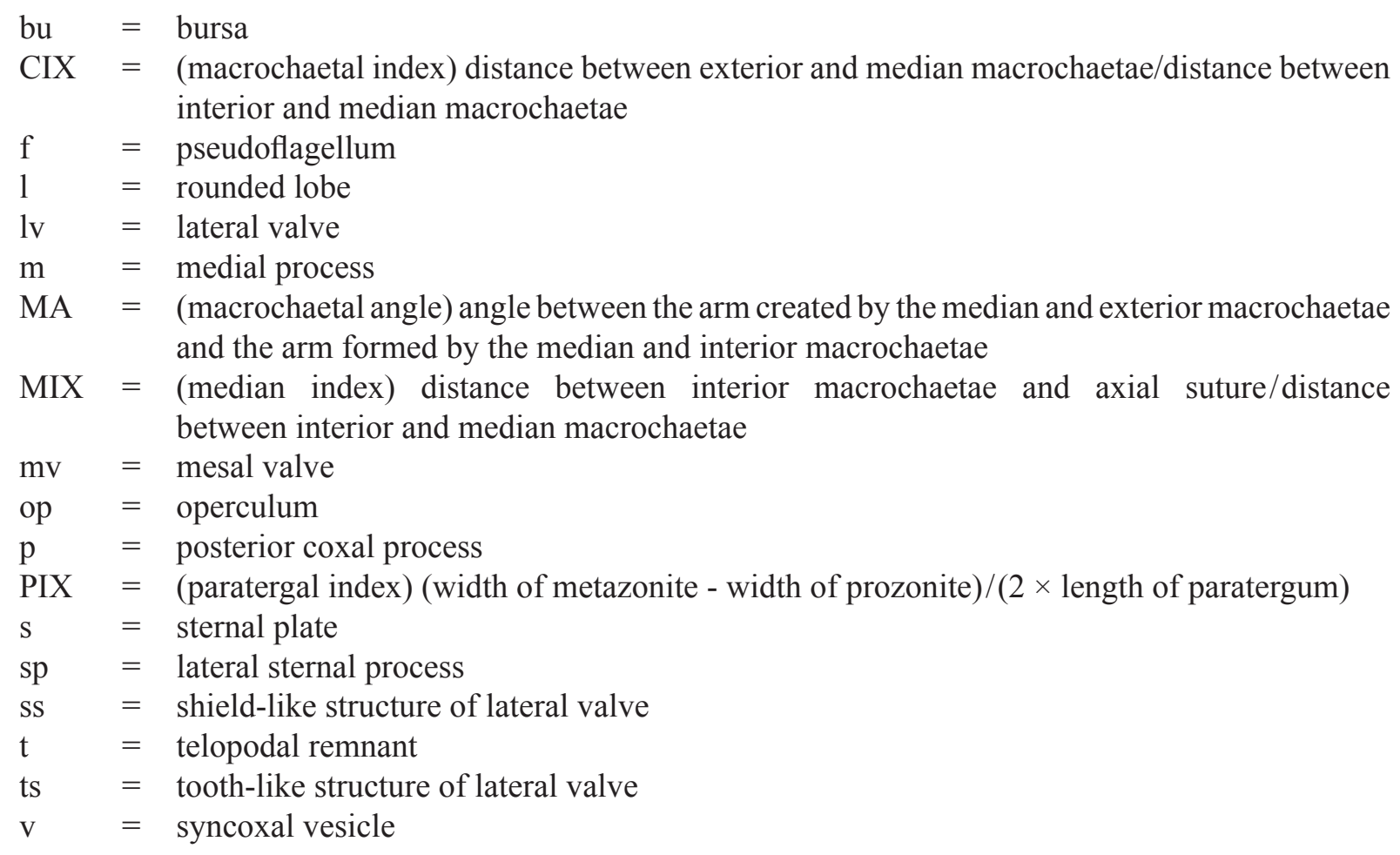

\section{Other abbreviations used}

CBSS = Croatian Biospeleological Society, Zagreb, Croatia

IZB = Institute of Zoology, University of Belgrade - Faculty of Biology, Belgrade, Serbia

NHMSC $=$ Natural History Museum, Split, Croatia

SEM = scanning electron microscope

\section{Results}

\section{Taxonomy}

Class Diplopoda Blainville-Gervais, 1844

Order Chordeumatida Pocock, 1894

Family Anthogonidae Ribaut, 1913

Anthroleucosomatidae Verhoeff, 1899: 130. (pro parte)

Acherosomatinae Verhoeff, 1930: 4.

Haasiinae Hoffman, 1980: 137.

Biokoviellidae Mršić, 1992: 53. syn. nov.

Subfamily Biokoviellinae stat. nov.

Nomen translatum ex family Biokoviellidae Mršić, 1992

Genus Biokoviella Mršić, 1992

This genus was established by Mršić (1992) for the type and until now only species, B. mauriesi (from caves and pits on Mt. Biokovo, Dalmatia, Croatia). The name is regarded as a feminine noun. 


\section{Type species}

Biokoviella mauriesi Mršić, 1992, by monotypy.

\section{Diagnosis}

This genus clearly differs from all other anthogonids in the presence of one pair of bristle apparatuses in combination with one pair of bristle-clad pseudoflagella on the anterior gonopods, while the posterior gonopods consist of coxal vesicles fused in the form of a medial process and telopodal remnants; without lateral coxal processes.

\section{Etymology}

The genus is named after its type locality, Mt. Biokovo.

\section{Included species}

Biokoviella mauriesi Mršić, 1992

Biokoviella mosorensis Antić \& Dražina sp. nov.

Biokoviella mauriesi Mršić, 1992

Figs $1-3,9 \mathrm{~A}, 10 \mathrm{~A}$

\section{Diagnosis}

Differs from B. mosorensis sp. nov. in larger body size, anterior gonopods that are more robust and several other details of their structure. Lateral valve of vulva with tooth-like subtriangular structures posteriorly.

\section{Etymology}

The species was named in honor of the well-known world expert in diplopodology Dr. Jean-Paul Mauriès.

Material examined (total: $13 \hat{\jmath}, 7 \stackrel{+}{\rho}, 9$ juveniles)

\section{Topotype}

CROATIA: ${ }^{\curvearrowright}$, Stara Ledenica Cave, $43.318^{\circ} \mathrm{N}, 17.050^{\circ} \mathrm{E}, 1350 \mathrm{~m}$ a.s.1., Biokovo Mountain, Dalmatia, 16 Jun. 2002, leg. R. Ozimec (IZB).

Other material (total: $12 \hat{\jmath}, 7 q q, 9$ juveniles)

CROATIA, Dalmatia, Mt. Biokovo: 4 ठ̄ $\widehat{\jmath}$, Jama kraj Stare Škole Pit, Lokva, 12. Jul. 1989, leg. B. Jalžić (CBSS); 2 $\widehat{\partial}$, Jama Čavlenovača Pit, 18 Jun. 2002, leg. R. Ozimec (CBSS); $2 \hat{\jmath}$ ô, 2 우, 2 juveniles, Jama pod Sv. Jurom Pit, below Sv. Jure Peak, 20 Jun. 2002, leg. R. Ozimec (CBSS); 1 q, Kašogijeva Jama Pit, below Sv. Jure Peak, 21 Jul. 2002, leg. M. Lukić (CBSS); 1 q, 1 juvenile, Lovricia Jama 2 Pit, 26 Jul. 2002, leg. J. Bedek (CBSS); 1 స, 1 juvenile, Jezero Ledenica Cave, Stražbenica, Kaoci, 20 Jul. 2003, leg. R. Ozimec (CBSS); 1 juvenile, Led 1 Pit, below Sv. Jure Peak, 21 Jul. 2003, leg. J. Bedek (CBSS); 1 ô, Crna Ledenica Cave, below Sv. Jure Peak, 24 Oct. 2006, leg. M. Lukić (CBSS); 1 q, same data except 18. Jun. 2011, leg. A. Kirin (CBSS); 1 đ̂, 1 q, 3 juveniles, Velika Mačka Pit, Velika Mačka, 22 Jun. 2008, leg. M. Lukić (CBSS); 1 juvenile, same data except leg. S. Nižetić (CBSS); 1 ठૈ, 1 , Lovricia 3 Pit, Lipi Doćić, 30 May 2015, leg. T. Delić (IZB).

\section{Type locality}

Stara Ledenica Cave, Mt. Biokovo, Dalmatia, Croatia. 


\section{ANTIĆ D.Ž. et al., Taxonomic status of Biokoviellidae}
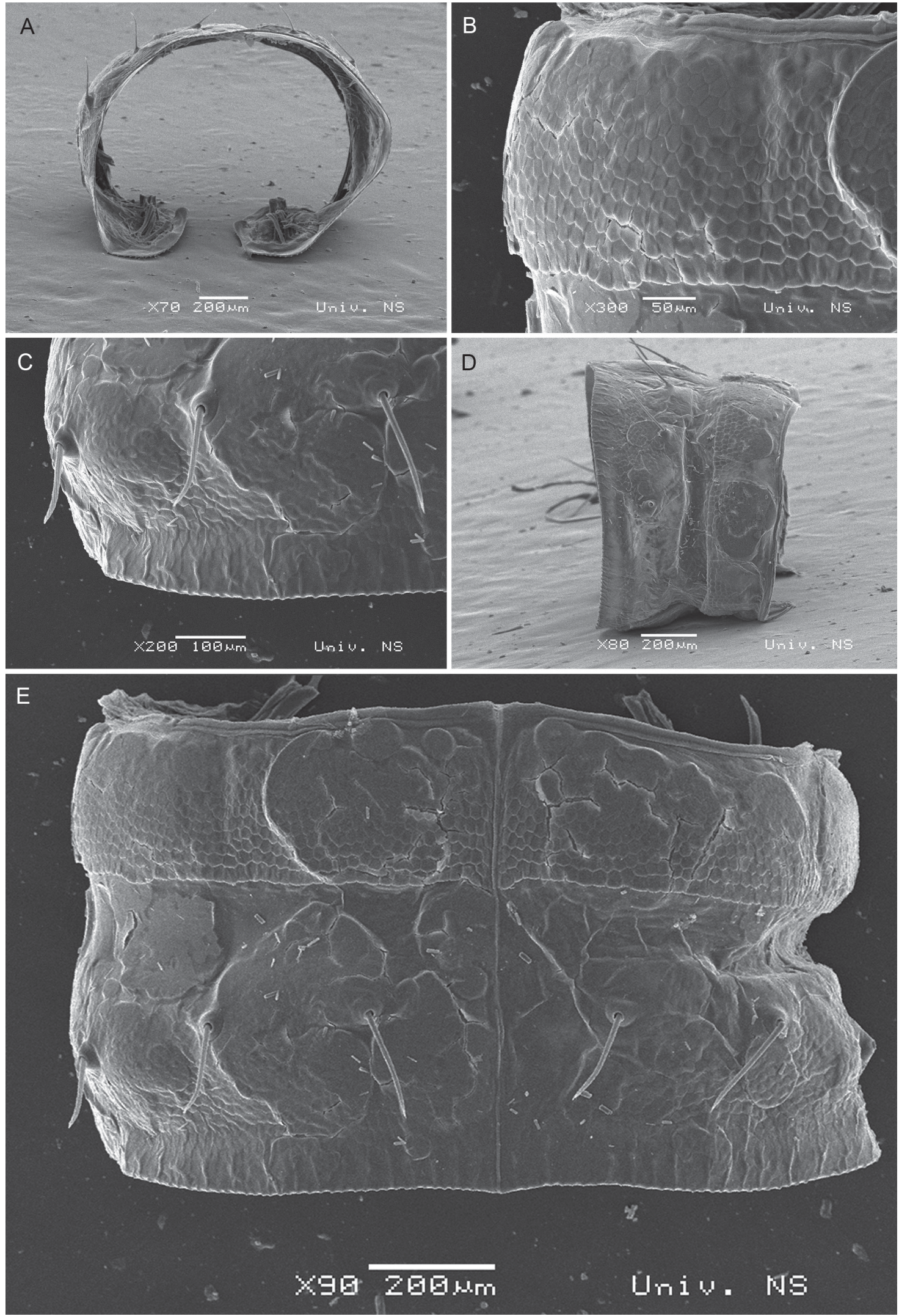

Fig. 1. Biokoviella mauriesi Mršić, 1992, đ̂, topotype, pleurotergite 15. A. Posterior view. B. Prozonite, dorsal view. C. Metazonite, dorsal view. D. Lateral view. E. Dorsal view. 


\section{Redescription}

\section{Body indices}

Pleurotergite 15 (Fig. 1). CIX $\sim 0.8$; MIX $\sim 0.8$; PIX $=0.25$; MA $\sim 160^{\circ}$.
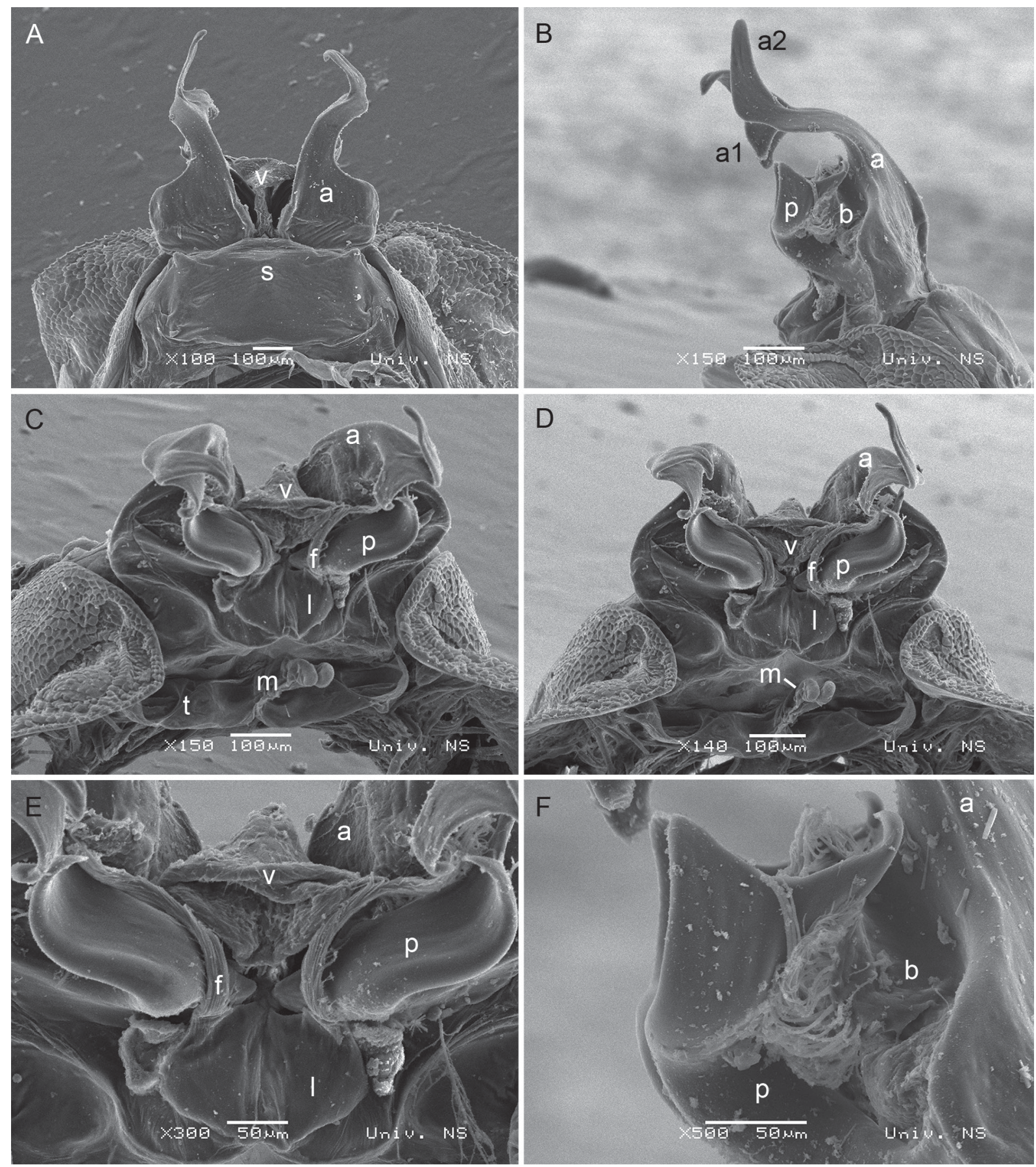

Fig. 2. Biokoviella mauriesi Mršić, 1992, Ô, topotype, gonopods. A. Anterior gonopods, anterior view. B. Anterior gonopods, lateral view. C-D. Anterior and posterior gonopods, postero-distal view. E. Anterior gonopods, postero-distal view of the medial part. F. Anterior gonopods, lateral view of the posterior process and bristle apparatus. Abbreviations: see Material and methods. 


\section{Redescription of male sexual characters}

MALE SEXUAL CHARACTERS. Leg pairs 3-7 are somewhat larger than the rest of the legs, leg pairs 3 and 4 the most robust; without any peculiarities (see Discussion).

ANTERIOR GONOPODS (Fig. 2). Anterior coxal processes (a) [= angiocoxites sensu Mršić (1992)] completely separated from each other, rising from the wide subquadrangular sternal plate (s); first $1 / 3$ (base) very broad, remaining $2 / 3$ very slender and long, curved caudad, apically with two branches (a1 and a2)
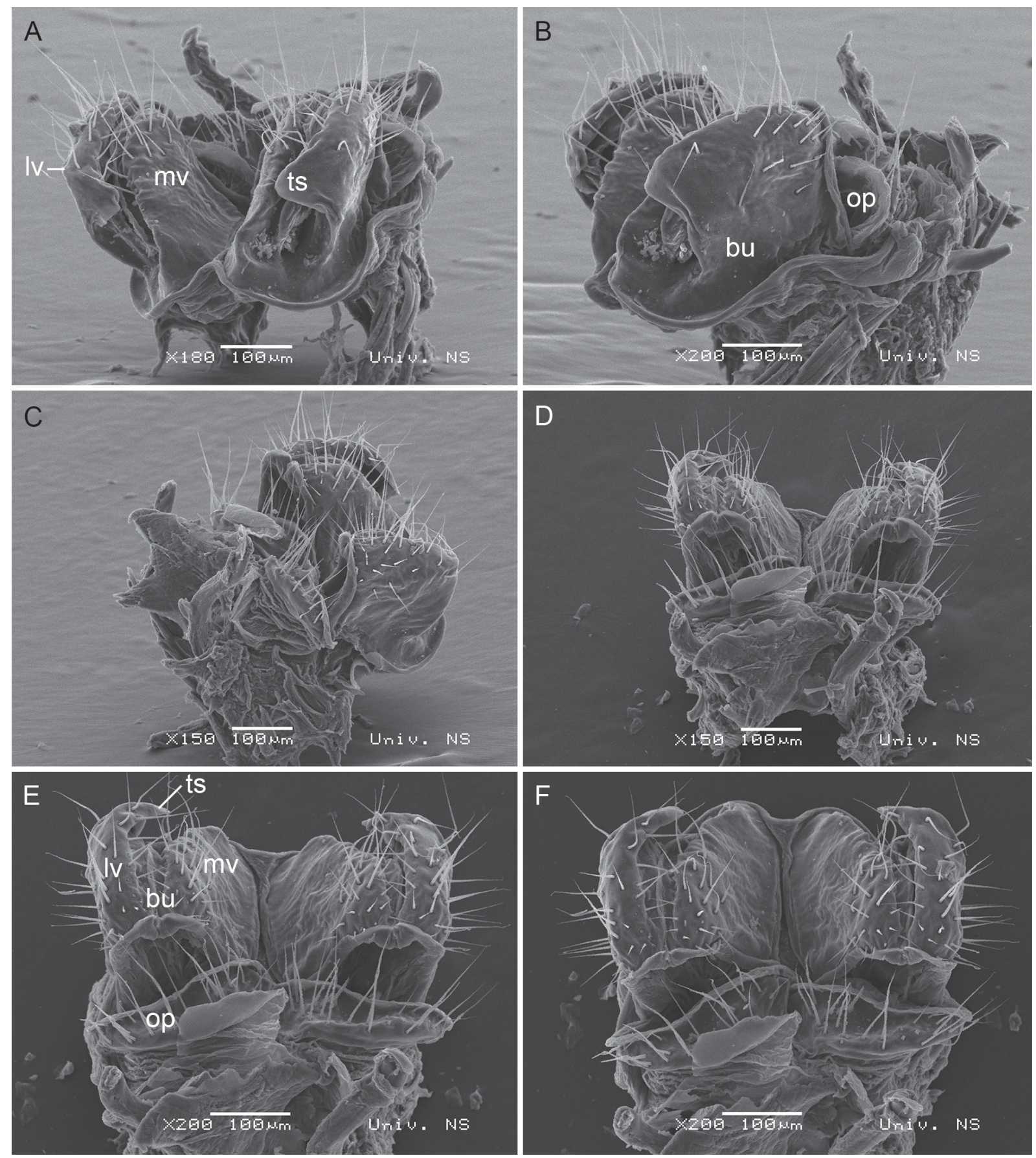

Fig. 3. Biokoviella mauriesi Mršić, 1992, q from the Lovricia 3 Pit, vulvae. A. Posterior view. B. Lateral view. C. Latero-distal view. D. Anterior view. E. Antero-distal view. F. Distal view. Abbreviations: see Material and methods. 
opposite to each other. Posteriorly, anterior coxal processes equipped with bristle apparatuses (b) [= oval coxal intermediate process with bristles sensu Mršić (1992)]. Posterior coxal processes (p) [= syncoxal processes sensu Mršić (1992)] well-developed, broad at the base, "C"-curved in posterior view, apically divided into two parts, very wide in lateral view. The most posterior parts of the anterior gonopods are a pair of pseudoflagella (f) covered by bristles over almost their whole length, with tassels at the top (see Discussion). These pseudoflagella starting from the well-developed, rounded lobes (1). The only unpaired part of the anterior gonopods, apart from the sternum, is the rounded syncoxal vesicle $(v)[=a$ small intermediate (medial) bridge sensu Mršić (1992)] situated between the coxal processes (deflated on the SEM photos). There are no traces of telopodites.

Posterior Gonopods (Figs 2C-D, 9A). Very reduced in both size and structure. Consist of coxal vesicles fused in the form of a medial process (m) apically divided. Laterally with telopodal remnants (t). Lateral sternal processes ( $\mathrm{sp}$ ) high and subtriangular.

\section{Descriptions of vulvae}

Vulvae (Fig. 3). Somewhat elongated from lateral view. Mesal (mv) and lateral (lv) valves of bursae (bu) distally with long setae. Several setae are present on the lateral side of the lateral valvae. Lateral valvae posteriorly with tooth-like subtriangular structures (ts), which only partly cover the mesal valvae, so the bursa apertures can be seen from posterior view. Operculum (op) with long setae.

\section{Distribution}

Croatia: known only from several caves on Mt. Biokovo (Fig. 11, red triangles).

\section{Habitat}

Biokoviella mauriesi is limited to deep and cold caves on Mt. Biokovo with temperatures ranging from 0 to $7^{\circ} \mathrm{C}$. The entrances of these caves are situated on an elevated plateau stretching from above $1300 \mathrm{~m}$ a.s.l. to the highest parts of Biokovo.

Biokoviella mosorensis Antić \& Dražina sp. nov. urn:1sid:zoobank.org:act:6270477C-2572-4DBC-80A3-937677DE8949

Figs 4-8, 9B, 10B

\section{Diagnosis}

The new species can be clearly separated from B. mauriesi on the basis of the smaller body size, the presence of anterior gonopods that are much more gracile and differences in several other details of their structure. Lateral valve of vulva with shield-like structures posteriorly.

\section{Etymology}

The new species is named after Mt. Mosor (Middle Dalmatia, Croatia), its terra typica.

Material studied (total: $14 \hat{\jmath} \hat{\partial}, 17 \stackrel{+}{\rho}, 4$ juveniles)

\section{Holotype}

CROATIA: O̊, Balića Špilja Cave (= Kraljeva Peć Cave), $43.573^{\circ}$ N, $16.570^{\circ}$ E, 404 m a.s.1., Balići, village of Dugopolje, Mt. Mosor, Middle Dalmatia, Croatia, 7 Sep. 2015, leg. D. Antić \& T. Rađa (NHMSC).

Paratypes (total: $10 \hat{\jmath}, 10 \uparrow q, 4$ juveniles)

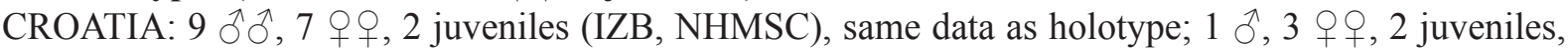
same data except 28 Apr. 2012, leg. M. Pavlek (CBSS). 
ANTIĆ D.Ž. et al., Taxonomic status of Biokoviellidae
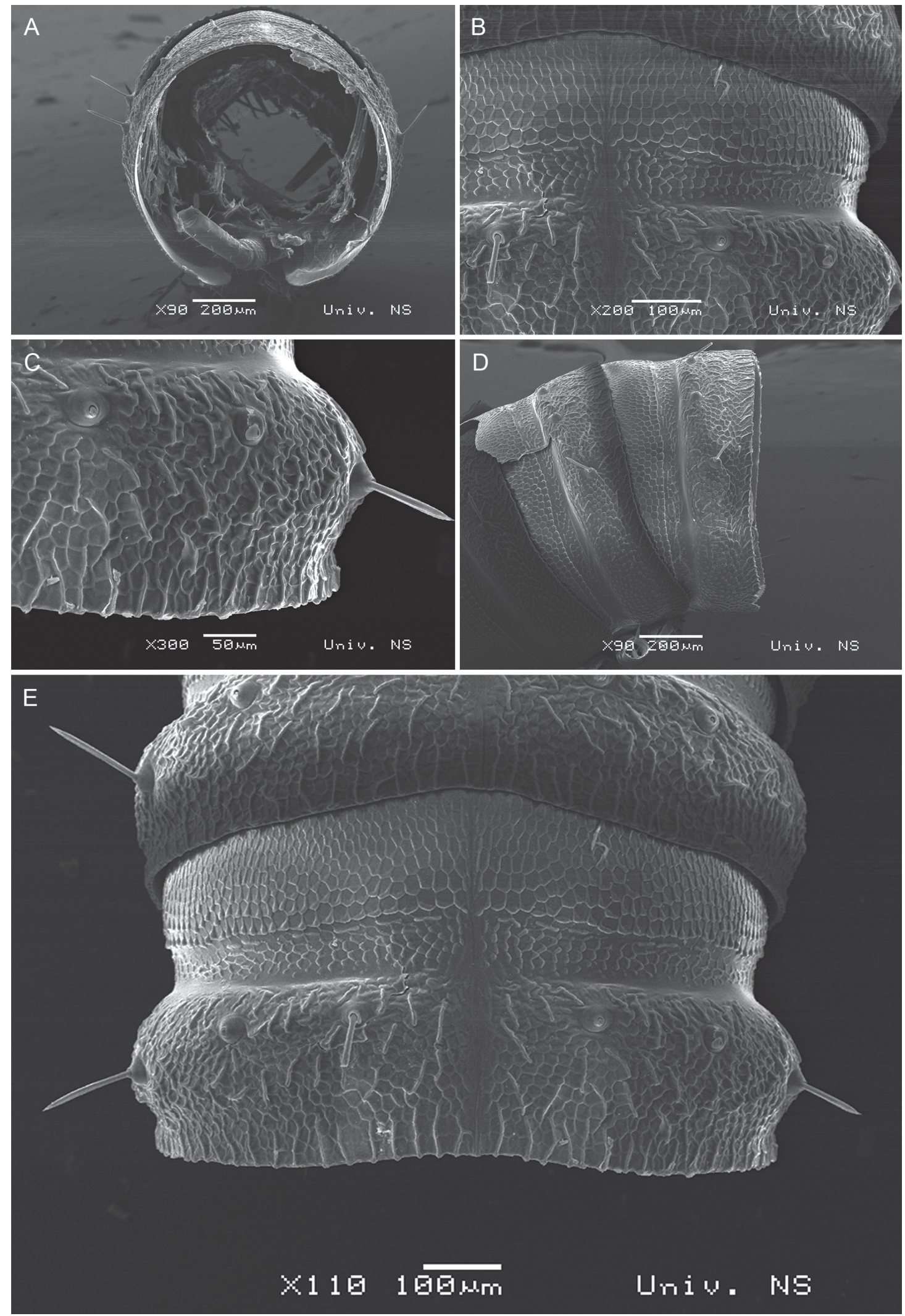

Fig. 4. Biokoviella mosorensis Antić \& Dražina sp. nov., đ̂, paratype. A. Pleurotergite 15, posterior view. B. Pleurotergite 15, prozonite and metazonite, dorsal view. C. Pleurotergite 15, metaznonite, dorsal view. D. Pleurotergites 14 and 15, lateral view. E. Pleurotergites 14 and 15, dorsal view. 
Other material (total: $3 \hat{\jmath} \widehat{\partial}, 7$ 우)

CROATIA, Mt. Mosor: 1 , Ledenica pod Jabukovcem Pit, Jabukovac, 23 Jun. 2011, leg. P. Bregović (CBSS); 1 + , Maklutača Špilja Cave, Čevrljin Klen, Kute, 24 Jun. 2011, leg. R. Baković (CBSS); 1 đ, Velika Gajna Pit, Gornje Sitno, 5 May 2012, leg. R. Cvitanić (CBSS); 2 đ̂̉, 5 우, same data except 7 Jun. 2015, leg. B. Jalžić (CBSS).
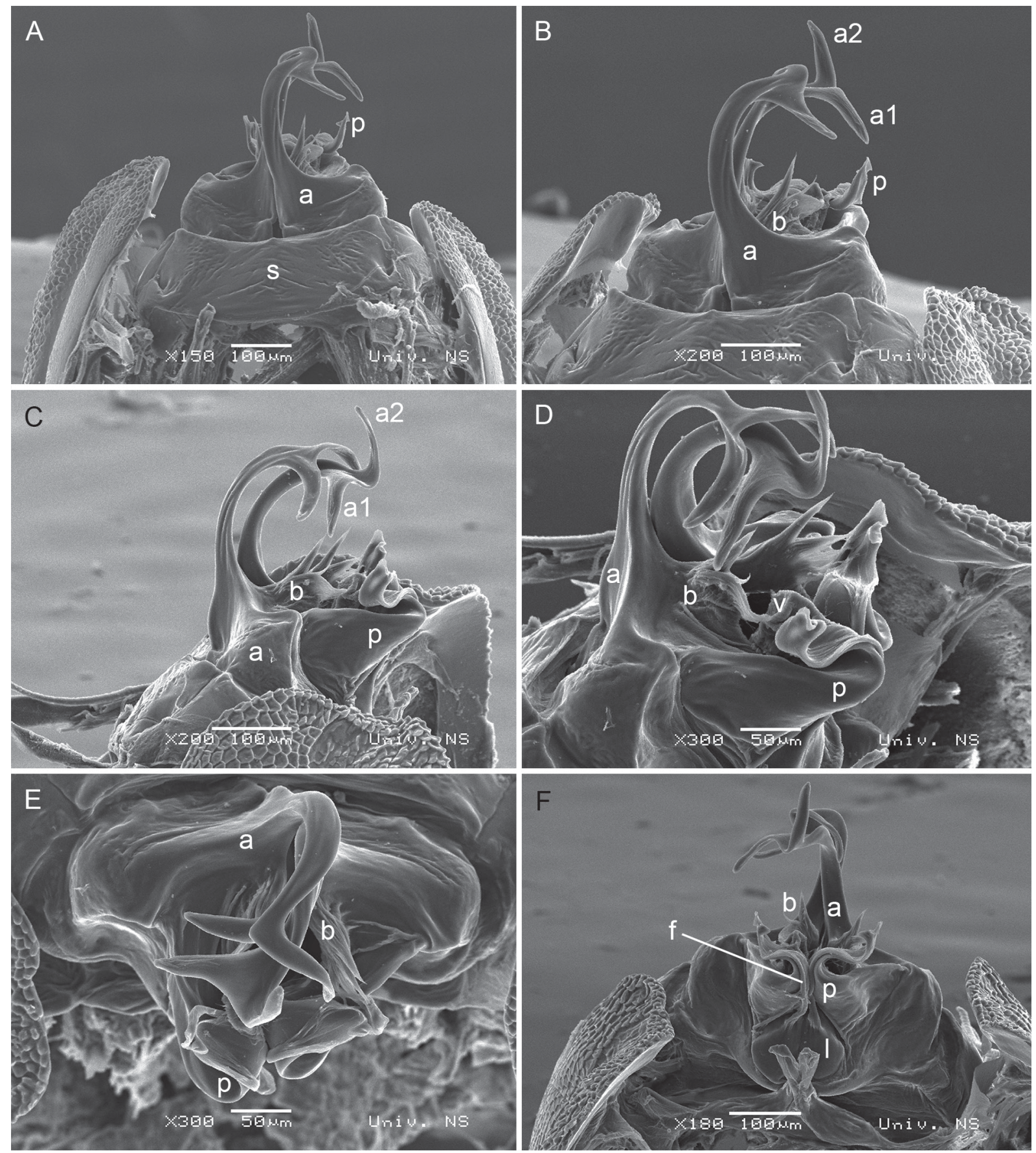

Fig. 5. Biokoviella mosorensis Antić \& Dražina sp. nov., đ̂, paratype, gonopods. A. Anterior gonopods, anterior view. B. Anterior gonopods, antero-lateral view. C. Anterior gonopods, lateral view. D. Anterior gonopods, latero-distal view. E. Anterior gonopods, distal view. F. Anterior and posterior gonopods, posterior view. Abbreviations: see Material and methods. 


\section{Type locality}

CROATIA: Balića Špilja Cave (= Kraljeva Peć Cave), Balići, village of Dugopolje, Mt. Mosor, Middle Dalmatia.
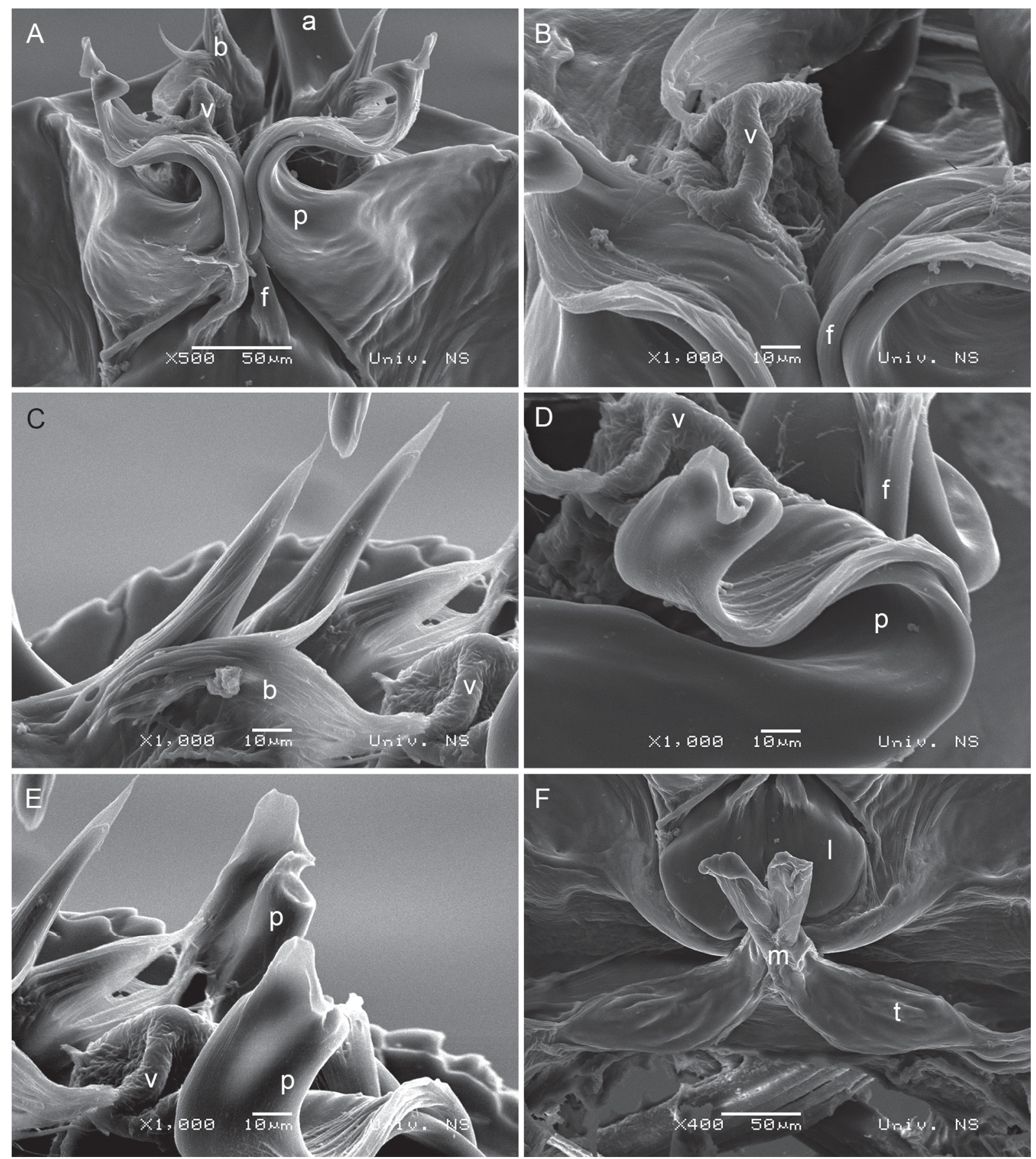

Fig. 6. Biokoviella mosorensis Antić \& Dražina sp. nov., đ’, paratype, gonopods. A. Anterior gonopods, posterior view. B. Anterior gonopods, postero-distal view of vesicle. C. Anterior gonopods, lateral view of bristle apparatus. D. Anterior gonopods, latero-distal view of posterior coxal process and vesicle. E. Anterior gonopods, lateral view of the apex of posterior coxal processes. F. Posterior gonopods, postero-distal view. Abbreviations: see Material and methods. 


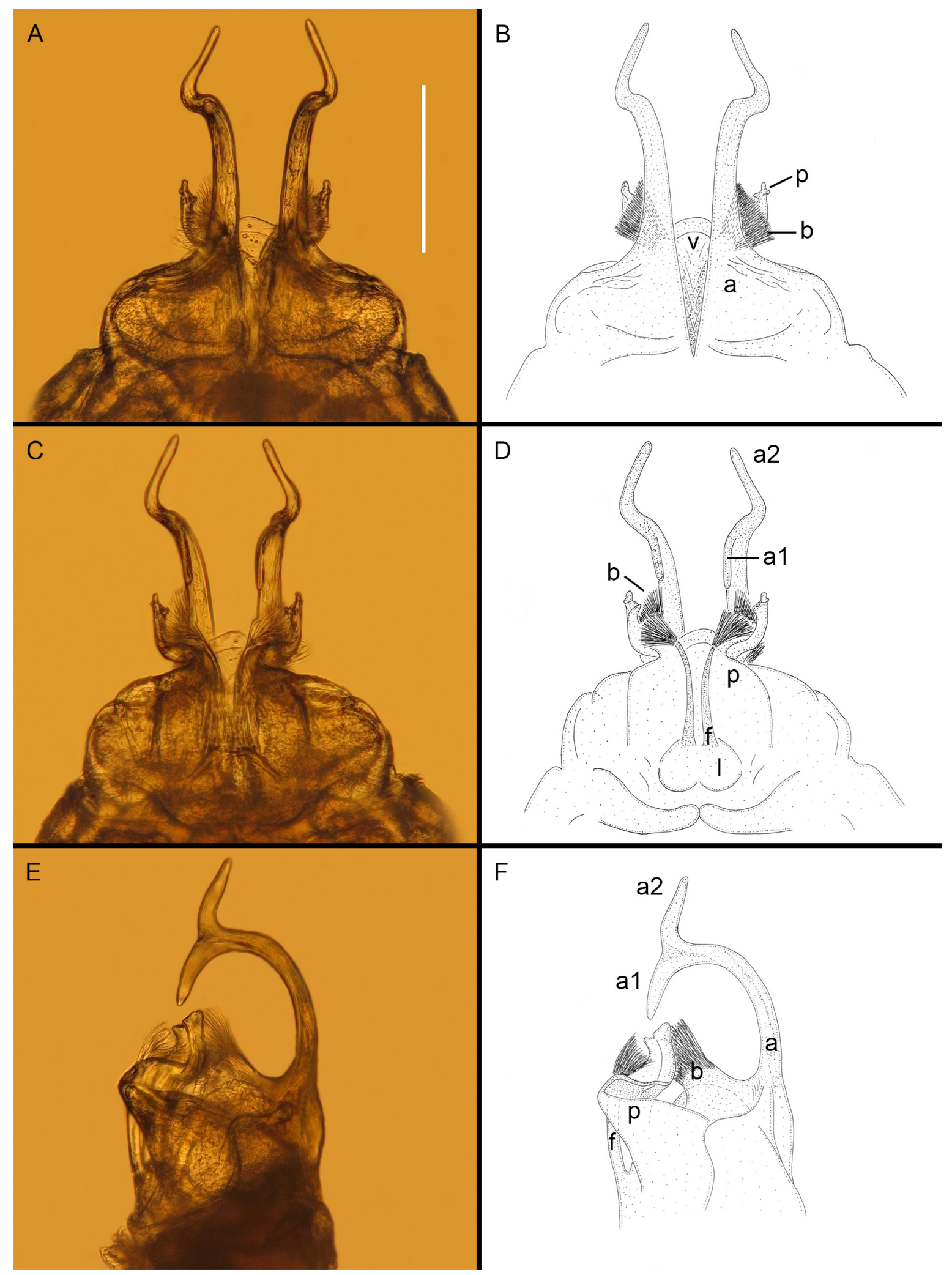

Fig. 7. Biokoviella mosorensis Antić \& Dražina sp. nov., §, holotype, anterior gonopods. A-B. Anterior view. C-D. Posterior view. E-F. Lateral view. Abbreviations: see Material and methods. Scale line $=$ $0.2 \mathrm{~mm}$. 


\section{Description}

SEgments. Body with 30 segments (including telson) in adults. Juveniles with 28 and 26 segments (including telson), respectively.

Measurements. Males 9-12 mm long, vertical diameter of the largest pleurotergite $0.9-1 \mathrm{~mm}$. Females $10.5-13 \mathrm{~mm}$ long, vertical diameter of the largest pleurotergite $1-1.05 \mathrm{~mm}$. Holotype male $10.5 \mathrm{~mm}$ long, vertical diameter of its largest pleurotergite $1 \mathrm{~mm}$.

Coloration. Pigmentless, whitish (Fig. 10B).

HeAd. Setose. Labrum with three medial labral teeth and with $4+4$ labral and $1+1$ supralabral setae. Gnathochilarium normal. Antennae elongated, $2.4 \mathrm{~mm}$ long in holotype male. Length of antennomeres (in mm): I (0.1), II (0.27), III (0.58), IV (0.3), V (0.7), VI (0.22), VII (0.2) and VIII (0.03). Length/ breadth ratios of antennomeres I-VII: I (1), II (2.1), III (5.3), IV (2.7), V (5.4), VI (1.5) and VII (2). Antennomeres II, IV, V, VI and VII with one, three, one, four and one macrochaetae, respectively. Blind.

Collum. Narrower than head, with six macrochaetae.

Body SEgMENTS (Fig. 4). Without lateral keels, metazonites with only small lateral swellings. Macrochaetae short, trichoid. CIX (pleurotergite 15) 0.9; MIX (pleurotergite 15) 1; PIX (pleurotergite 15) =0.6; MA (pleurotergite 15) $\sim 140^{\circ}$.

TELSON. Epiproct with a pair of spinnerets and six trichoid setae arranged in two rows $(2+2$ marginal and 1+1 paramedial setae). Hypoproct with two trichoid setae. Paraprocts with $3+3$ marginal trichoid setae.

WALKING LEGS. Elongated. Leg pairs 1 and 2 with tarsal combs in both sexes.

MALE SEXUAL CHARACTERS. Leg pairs 3-7 somewhat larger than the rest of the legs, leg pairs 3 and 4 the most robust; without any peculiarities. Leg pairs 10 and 11 with coxal glands; leg pair 11 with posteriorly directed coxal horn.

ANTERIOR GONOPODS (Figs 5, 6A-E, 7). Anterior coxal processes (a) [= angiocoxites sensu Mršić (1992)] completely separated from each other, rising from the very wide sternal plate (s); first $1 / 3$ (base) very broad, remaining $2 / 3$ very gracile, long, thin and curved caudad, apically with two branches (a1 and a2) opposite to each other. Posteriorly anterior coxal processes with bristle apparatuses (b) [= oval coxal intermediate process with bristles sensu Mršić (1992)]. Posterior coxal processes (p) [= syncoxal processes sensu Mršić (1992)] well-developed, broad at the base, "S"-curved from posterior view, with only a small apical notch. The most posterior parts of the anterior gonopods are a pair of pseudoflagella (f), naked over their whole length, with tassels at the top. These pseudoflagella starting from the welldeveloped, rounded lobes (1). The only unpaired part of the anterior gonopods, apart from the sternum, is the rounded syncoxal vesicle (v) [= small intermediate (medial) bridge sensu Mršić (1992)] situated between the coxal processes (deflated on the SEM photos). There are no traces of telopodites.

Posterior GONOPODS (Figs 6F, 9B). Very reduced in both size and structure. Consisting of coxal vesicles fused in the form of a medial process $(\mathrm{m})$ divided halfway. Laterally with telopodal remnants ( $\mathrm{t}$ ). Lateral sternal processes (sp) low and rounded.

Vulvae (Fig. 8). Subquadrangular from lateral view. Mesal (mv) and lateral (lv) valvae of bursae (bu) distally with long setae. Lateral valvae posteriorly with shield-like structures (ss) which almost completely cover the mesal valvae, so that bursa apertures can't be seen from posterior view. Operculum (op) with long setae. 

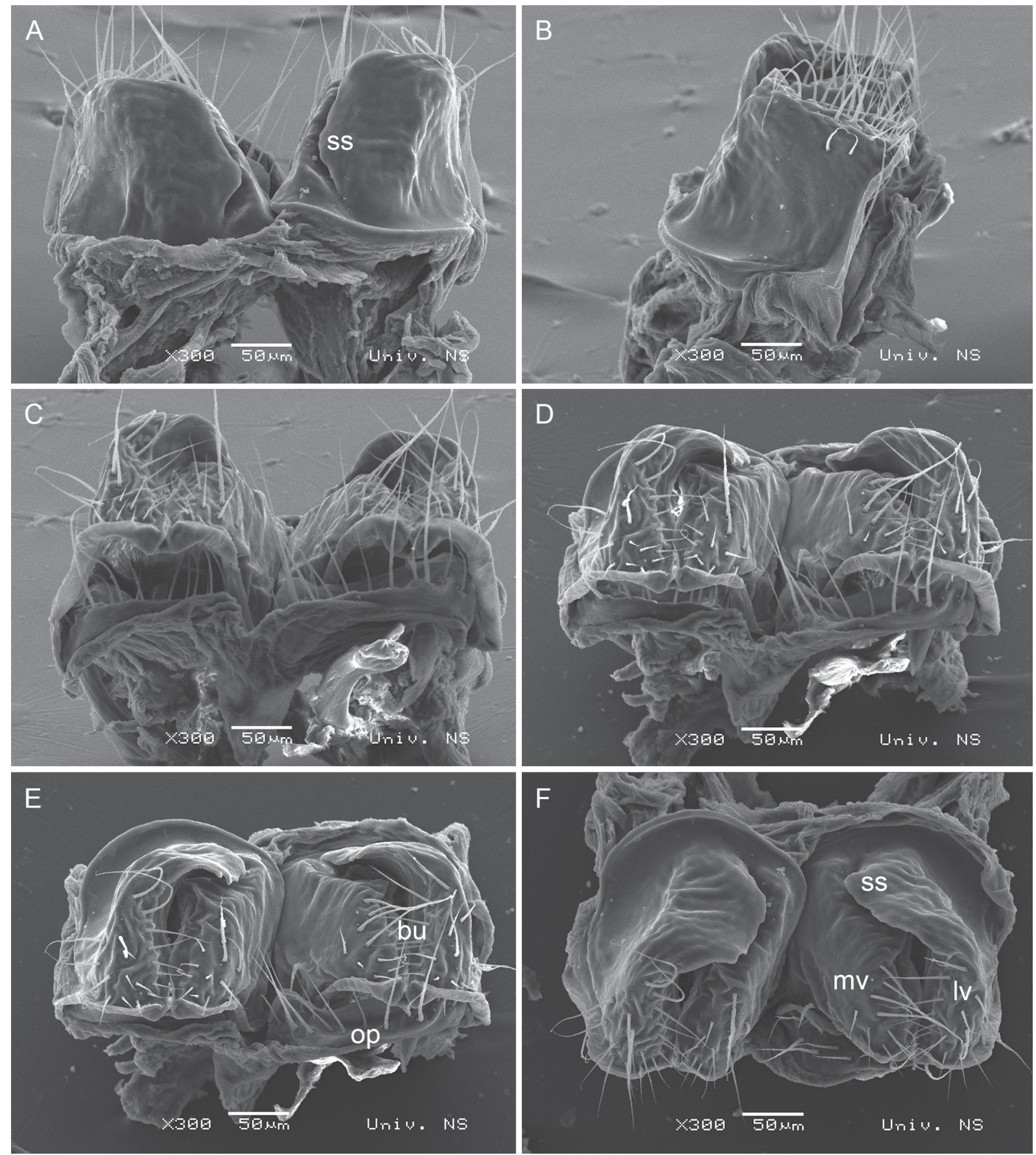

Fig. 8. Biokoviella mosorensis Antić \& Dražina sp. nov., , +, paratype, vulvae. A. Posterior view. B. Lateral view. C. Anterior view. D. Antero-distal view. E. Distal view. F. Postero-distal view. Abbreviations: see Material and methods. 


\section{Distribution}

Croatia, known only from several caves on Mt. Mosor (Fig. 11, blue circles).

\section{Habitat}

Balića Špilja is a cave with a huge entrance enabling light to penetrate through almost the whole cave. Only the innermost part is in compete darkness and with various speleothems. Mean air temperature in the cave is $6.3^{\circ} \mathrm{C}$ and humidity is high $(99.6 \%)$. Altogether, the cave is $194 \mathrm{~m}$ long and $50 \mathrm{~m}$ deep. Balića

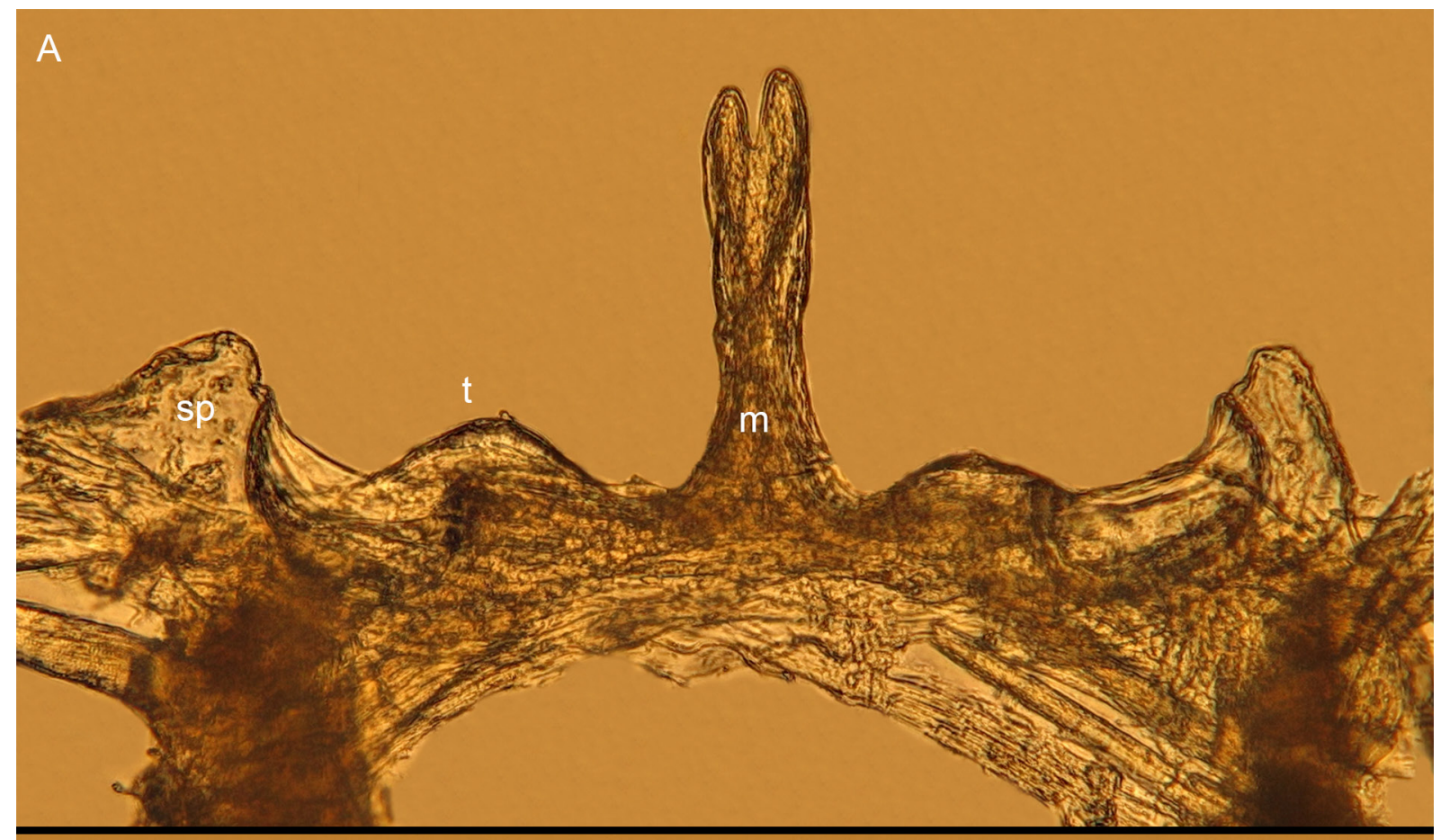

B

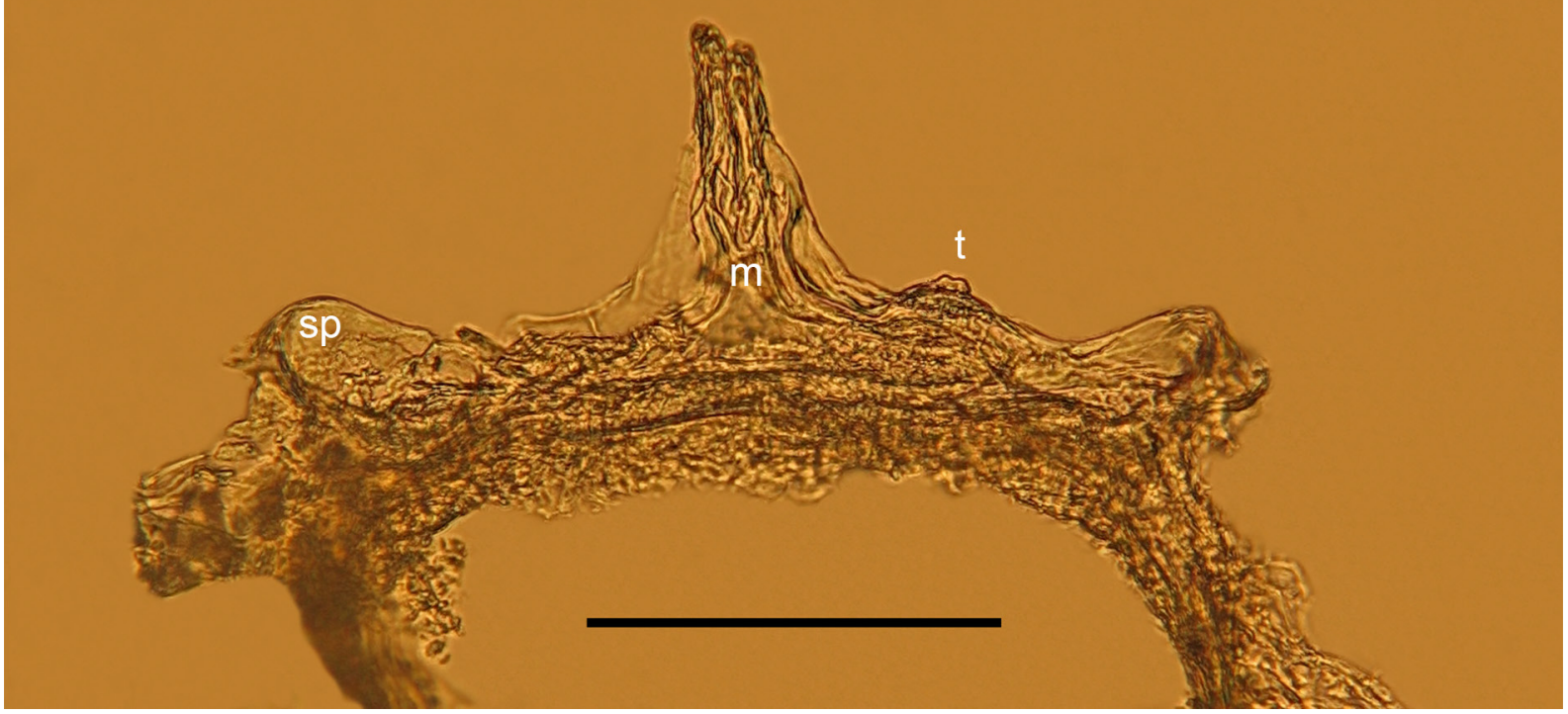

Fig. 9. Posterior gonopods. A. Biokoviella mauriesi Mršić, 1992, ô from the Lovricia 3 Pit. B. Biokoviella mosorensis Antić \& Dražina sp. nov., ổ, holotype. Abbreviations: see Material and methods. Scale line $=0.2 \mathrm{~mm}$. 

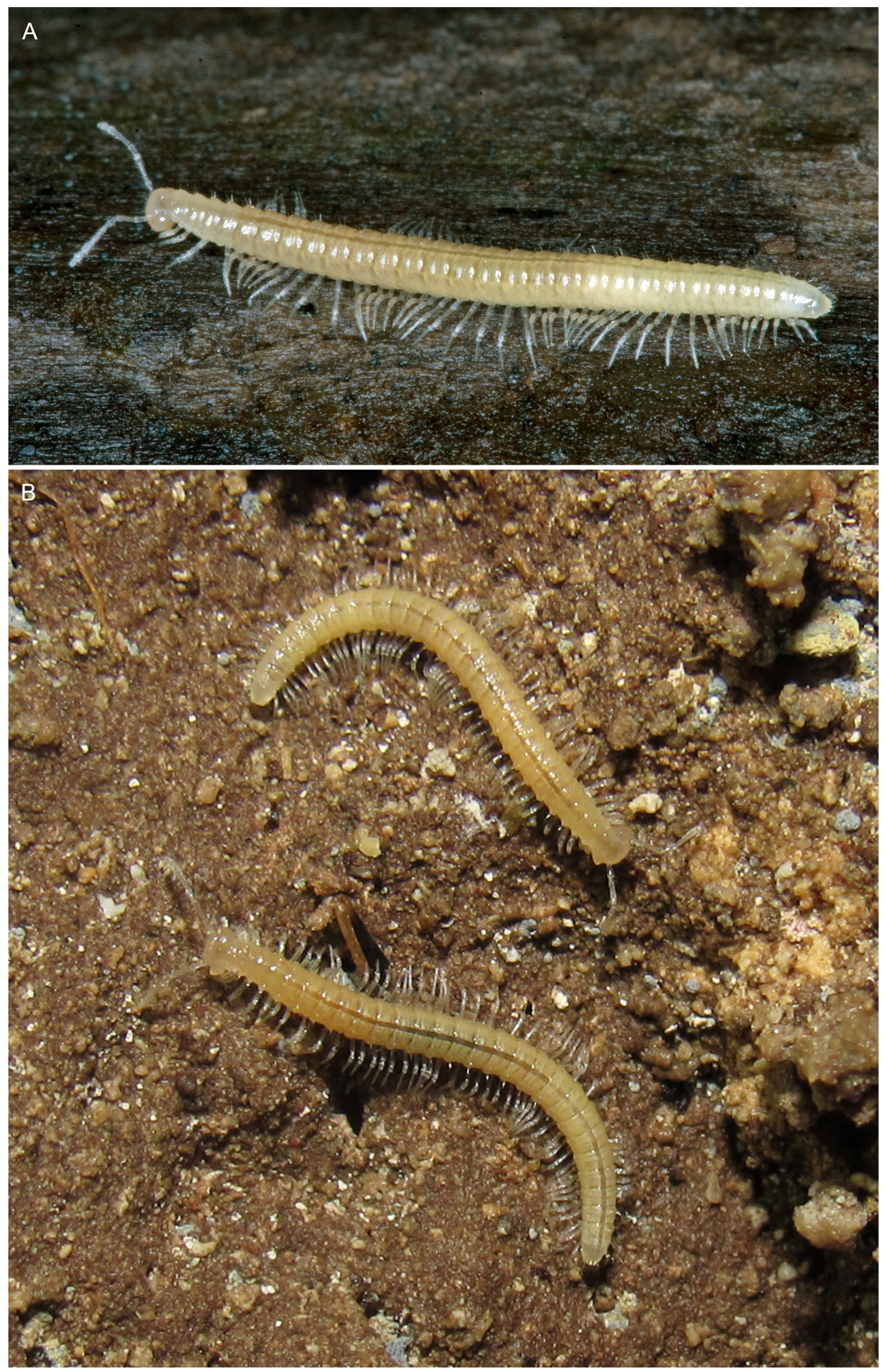

Fig. 10. Habitus. A. Biokoviella mauriesi Mršić, 1992, q, topotype (photo by H. Bilandžija). B. Biokoviella mosorensis Antić \& Dražina sp. nov., $\hat{\sigma}$ and $q$ from the type serie (photo by D.A.). Without scale. 
Špilja is a very important biospeleological locality, being locus typicus for eight different taxa (Bedek et al. 2006; Makarov et al. 2011): Folkia boudewijni Deeleman-Reinhold, 1993, Troglohyphantes giromettai (Kulczyński, 1914) and Troglohyphantes strandi Absolon \& Kratochvíl, 1932 (all Araneae); Neobisium dalmatinum Beier, 1938 (Pseudoscorpiones); Massarilatzelia dugopoljica Makarov \& Rađa, 2011 (Diplopoda); and Neotrechus ganglbaueri bluehweissi (Hoffmann, 1913), Haplotropidius taxi subinflatus (Apfelbeck, 1907) and Spelaites grabowskii Apfelbeck, 1907 (all Coleoptera). Apart from the aforementioned taxa, the cave is also inhabited by another interesting troglobiont or trogophile fauna, including such species as: Oroniscus dalmaticus Strouhal, 1937, Alpioniscus balthasari (Frankenberger, 1937) and Armadillidium sp. (all Isopoda, Bedek et al. 2011 and CBSS); Apfelbeckia insculpta (L. Koch, 1867) and Brachydesmus subterraneus Heller, 1858 (both Diplopoda, present study); Nesticus eremita Simon, 1879, Rhode sp., Stygopholcus absoloni (Kulczyński, 1914) and Barusia maheni (Kratochvil \& Miller, 1939) (all Aranea, CBSS); and Duvalius novaki (Müller, 1911) (Coleoptera, Pretner 1973). Biokoviella mosorensis sp. nov. is found in the middle part of the cave, walking on rocks or large stones on surfaces facing the dark.

With a depth of $176 \mathrm{~m}$, Velika Gajna Pit is one of the deepest pits on Mt. Mosor. Biokoviella mosorensis sp. nov. was collected near the bottom of this pit, where measured air temperature was $7^{\circ} \mathrm{C}$ and humidity $90 \%$. Other notable collected species of the pit's fauna were: Alpioniscus sp. (Isopoda); Brachydesmus subterraneus Heller, 1858 (Diplopoda); and Duvalius erichsonii (Schaufuss, 1864), Haplotropidius taxi (Müller, 1903), Laemostenus cavicola (Schaum, 1858), S. grabowskii and Speoplanes giganteus (J. Müller, 1911) (all Coleoptera) (Jalžić et al. 1990 and CBSS).

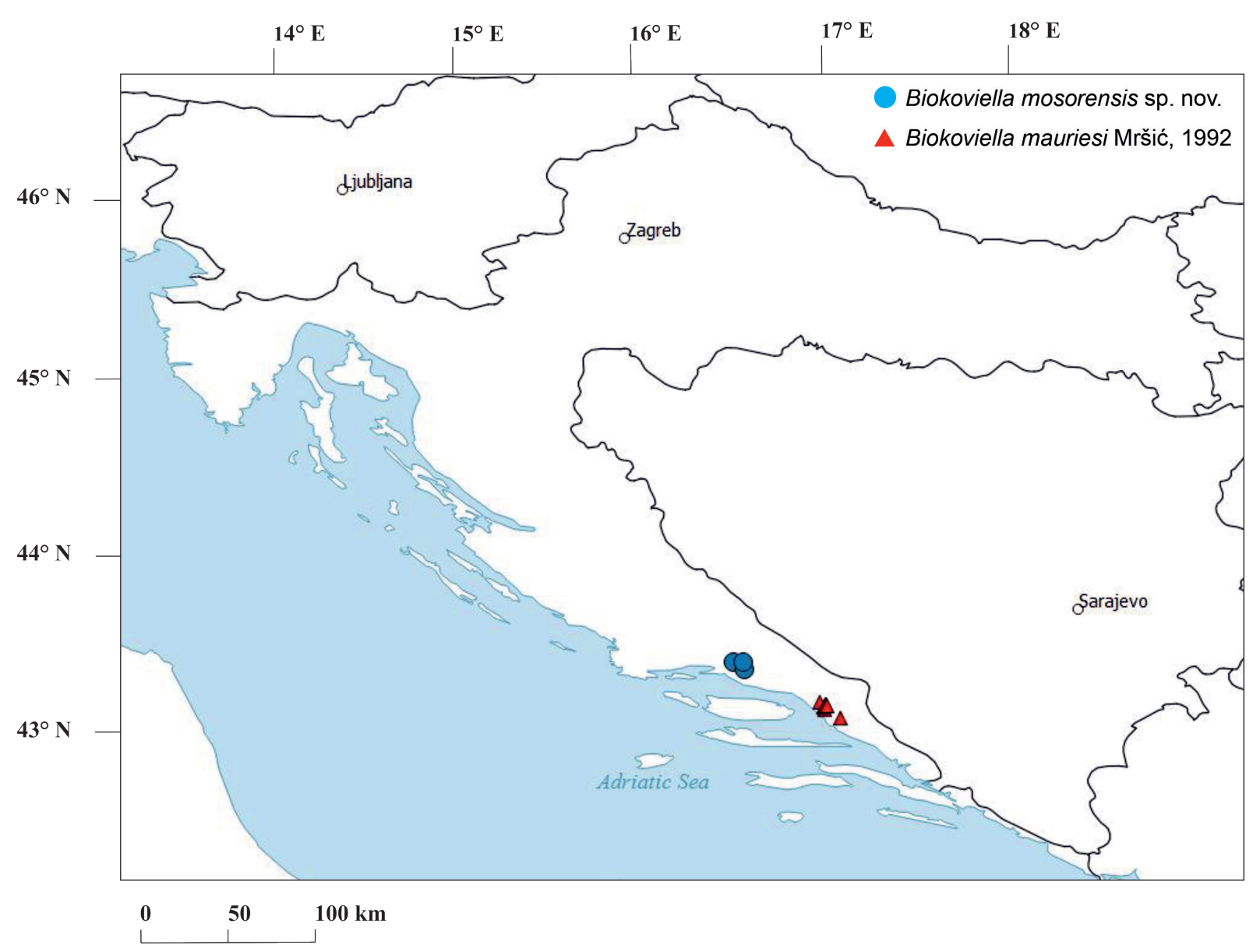

Fig. 11. Distribution of the subfamily Biokoviellinae stat. nov. 
Maklutača is a cave almost $150 \mathrm{~m}$ long and 39 deep (Jalžić et al. 2013). Similar to Balića Špilja, Maklutača has a huge entrance, with light penetrating through the first half of the cave. Measured air temperature was $6.7^{\circ} \mathrm{C}$. This cave is the type locality of Nicoletiella absoloni absoloni Willmann, 1940, a subspecies of small troglobitic mite (Acari). The following troglobitic or troglophilic forms were also recorded from this locality: T. giromettai and T. strandi (both Aranea); A. balthasari (Isopoda, Bedek et al. 2011); Onychiuridae indet., Heteromurus (Verhoeffiella) sp. and Pseudosinella sp. (all Collembola, CBSS); and Neotrechus ganglbaueri (Padewieth, 1891) and H. taxi (Pretner 1973 and CBSS). Furthermore, another diplopod species, Massarilatzelia dugopoljica Makarov \& Rađa, 2011, was collected in Maklutača cave, which is the second known locality for this Mt. Mosor endemic species (present study).

The Ledenica pod Jabukovcem Cave is situated in a deep dolina, and its specific position enables it to retain snow and ice up to the summer months. For that reason air temperature is extremely low, on average around $3.6^{\circ} \mathrm{C}$. The cave has a total length of $105 \mathrm{~m}$ and depth of $34 \mathrm{~m}$ (Jalžić et al. 2013). This speleological locality is an important locus typicus, with three described taxa: Neobisium maderi Beier, 1938 (Pseudoscorpiones), Traegardhia dalmatina gigantea Willmann, 1941 (Acari) and Speoplanes giganteus giganteus (J. Müller, 1911) (Coleoptera). Pretner (1973) mentioned two additional species of Coleoptera for this cave: H. taxi and S. grabowskii.

\section{Notes on the ecology and distribution of Biokoviella}

Biokoviella mosorensis sp. nov. inhabits cold caves on Mt. Mosor, those in which the air temperature does not exceed $7^{\circ} \mathrm{C}$ and humidity ranges from 95 to $100 \%$. A similar ecological preference is also characteristic of $B$. mauriesi. Chordeumatidans are known to tolerate low temperature, and they can be active in the soil and in rocky crevices below the snow cover (Mauriès 1986, 1988). Thus, this group of diplopods is well adapted for colonization of cold underground habitats.

The subterranean habitats of Mts Biokovo and Mosor have diverse and endemic troglobiotic faunas. Turbulent geological history and the role of the Dinaric area as a refuge during glacial periods promoted continuous colonization of suitable underground habitats. A high rate of endemism is present throughout the entire Dinarides, and Mosor is no exception - even after more than 100 years of speleological and biospeleological research (Girometta 1914), new species are still being discovered.

\section{New data for some Balkan anthogonids}

\section{New data for Egonpretneria vudutschajldi Antić \& Dražina, 2015}

CROATIA: $2 \widehat{\jmath} \widehat{\jmath}, 1$ q, Pećina Čakovec Cave, Javorinske Drage, Mlakva, Perušić, 2 Aug. 2015, leg. B. Jalžić (CBSS); 2 ○ึ, 1 \&, Kalvarija Cave, Bužin, Gospić, 1 Sep. 2015, leg. H. Cvitanović (CBSS).

\section{New data for Haasia cornuata (Strasser, 1940)}

SLOVENIA: 1 đ̃, 1 juvenile, Veliki Mižuk Pit, Mokri Potok, 15 Dec. 2015, leg. T. Delić \& S. Polak (IZB).

\section{New data for Haasia stenopodium (Strasser, 1966)}

CROATIA: 1 ภ, 2 우, Pepelarica Pit, Middle Velebit, 4 Jul. 2015, leg. G. Rnjak (CBSS); 1 ภ, 3 우, Meduza Pit, Crikvena, North Velebit National Park, 4 Aug. 2015, leg. B. Jalžić (CBSS).

SLOVENIA: 1 क, Velika Ledenica u Paradani Pit, Lokve, Batuje, Nova Gorica, 6 Apr. 2014, leg. T. Delić \& Š. Borko (IZB); 1 ô, same data except Jun. 2014, leg. Š. Borko (IZB); 2 ô $\hat{0}, 1$ juvenile, Brezno Treh Src, Cifre, Snežnik, 12 Sep. 2015, leg. T. Delić (IZB); 1 ô, 2 qq , 2 juveniles, Brajnice Pit, Dobec, Bezuljak, 14 Nov. 2015, leg. T. Delić (IZB). 
ANTIĆ D.Ž. et al., Taxonomic status of Biokoviellidae

New data for Macrochaetosoma bertiscea Antić \& Makarov, 2015

MONTENEGRO: 2 juveniles, Trzy Kopce Pit, Prokletije Mountains, 17 Jul. 2015, leg. M. Petković (IZB).

\section{New data for Macrochaetosoma troglomontanum Absolon \& Lang, 1933}

CROATIA: 1 ô, 4 juveniles, Jama pod Gažnovcem Pit, Stilja, Vrgorac, 3 Aug. 2014, leg. T. Rađa (IZB); 3 juveniles, Martina Jama Pit, Stilja, Vrgorac, 9 Aug. 2015, leg. T. Rađa (IZB).

MONTENEGRO: 1 , Jama u Dubokomdolu Pit, Njeguši, no dates or leg. (IZB); 2 $q$, Ericova Jama Pit, Krivošije Mt., Crkvice, 20 Sep, 2006, leg. M. Perreau (IZB); 1 +, Opasna Jama Pit, Kučka Korita, 21 Jun. 2015, leg. M. Petković (IZB).

\section{Notes on the distribution of the Macrochaetosomatinae}

In a recent review of the family Anthogonidae, Antic et al. (2015) in their key to the anthogonid genera stated that the genus Macrochaetosoma Absolon \& Lang, 1933 is distributed in Croatia, Bosnia and Herzegovina, Montenegro and Serbia (?). In writing that review, we unfortunately overlooked a paper mentioning M. troglomontanum from caves in Albania (Stoev 2001).

\section{Discussion}

In their review of the family Anthogonidae Antić et al. (2015) recognized three subfamilies viz., Anthogoninae, Acherosomatinae and Macrochaetosomatinae, with 30 species. To the family Anthogonidae, we now add one more subfamily, Biokoviellinae, with two species.

As stated earlier, Mršić established a new monotypic family, Biokoviellidae, based on specimens from caves on Mt. Biokovo, even though he acknowledged some similarities with the families Anthogonidae and Chamaesomatidae. After examining the topotype male of B. mauriesi and specimens of B. mosorensis sp. nov., we recognized some mistakes in the descriptions of Biokoviella and found enough evidence to support inclusion of this genus in the family Anthogonidae and consequently synonymization of the family Biokoviellidae with the family Anthogonidae. On the other hand, new observation on the posterior gonopods show clear differences of the genus Biokoviella from all other anthogonid genera and supports recognition of the Biokoviellinae as a fourth subfamily within the family Anthogonidae.

According to Antić et al. (2015), the main taxonomic character of the family Anthogonidae is the presence of bristle apparatuses, a bristle-clad pseudoflagellum and several pseudoflagella on coxites of the anterior gonopods. These characters (bristle apparatuses and bristle-clad pseudoflagellum) can be seen in the genus Biokoviella. In his paper from 1992, Mršić mentioned the presence of bristled oval inner processes at the base of the posterior part of the anterior coxal processes and listed these structures as one of the similarities with the subfamily Acherosomatinae (Haasiinae sensu Mršić 1992). Such structures indeed exist in both Biokoviella species and are much hairier than in Mršićs drawing (see Mršić 1992: 57, fig. 2), especially in the new species (Fig. 7). These structures are very similar to, and definitely homologous with bristle apparatuses in the subfamily Macrochaetosomatinae, being placed in both taxa in the base of the posterior part of the anterior coxal processes (see Antic et al. 2015: figs 56-66, 76, 79, 84). Also, well-developed and high anterior coxal processes are present in some representatives of the subfamily Anthogoninae and especially the subfamily Acherosomatinae.

According to Mršić (1992), the presence of bristle-clad pseudoflagella in Biokoviella links it with the subfamily Scutogoninae (fam. Chamaesomatidae). One of the main characters of Scutogoninae is the presence of a single pair of flagella on the posterior side of the anterior gonopods. Such 
flagella in Scutogoninae are very different from the bristle-clad pseudoflagella in Biokoviella. It is therefore unnecessary to comment on the possibility of including the genus Biokoviella in the family Chamaesomatidae. Thus, Biokoviella cannot be linked with scutogonins. On the other hand, more similar, but still different, bristle-clad pseudoflagella are present in some Anthogoninae [Escualdosoma gourbaultae (Mauriès, 1965) and Vascanthogona vicenteae Mauriès \& Barraqueta, 1985]. After examining the topotype male of $B$. mauriesi and a male from another locality, we found some differences compared to the drawing by Mršić (1992), who presented these pseudoflagella as mascara brush (see Mršić 1992: 57, fig. 2), i.e., one rod with a bristle on the top. Our examination shows that these pseudoflagella are indeed equipped with bristles on the top, in the form of a tassel not a brush, but also with hairs over their entire length (Fig. 2E). On the other hand, in the new species, pseudoflagella are equipped with an apical tassel only.

The only unpaired structure on the anterior gonopods actually is not a bridge between the posterior coxal processes, but a rounded syncoxal vesicle, cited by Mršić (1992) as a "small intermediate bridge or little intermediate (medial) bridge (brace)". This vesicle starts from the base of the anterior gonopods, between the coxal processes. Clear evidence that this structure represents a vesicular structure is presented on the SEM photographs, where the vesicle in question is obviously deflated (Figs 2A, C-E, 6B-C, 6E) in contrast to anterior gonopods in situ, where the structure has globular shape (Fig. 7A-D, or see Mršić 1992: 57, fig. 2G). Such structures are also present in some other anthogonids and are especially developed in both species of Egonpretneria Strasser, 1966 (see Antić et al. 2015: 156, figs 12 and 16, sco; and Mršić 1992: 72, figs 2 and 7B). This structure probably represents fused coxal vesicles. On the other hand, in Macrochaetosomatinae coxal vesicles on the anterior gonopods are not fused but paired, and they are situated on the posterior part of those gonopods (see Antić et al. 2015: 167, fig. 60, cv; 172, figs 79 and 84, cv).

The similarity between the genus Biokoviella and Anthogonidae that Mršić (1992) saw also applied to the posterior gonopods. It is probable that he had in mind similarity of the medial process on the posterior gonopods. He stated that the posterior gonopods " [...] are merely sternite remnants, with no coxal part at all" and that "In the middle the medial sternite process is situated". The medial process of the posterior gonopods in the subfamilies Acherosomatinae and Macrochaetosomatinae is indeed of sternal origin (see Antić et al. 2015). As a result of examining the posterior gonopods of both Biokoviella species under a scanning electron microscope, we think that Mršić was wrong when he wrote that the medial process of the posterior gonopods is of sternal origin. To judge from the SEM and light microscope photos (Figs 2C-D, 5F, 6F, 9), it seems that this medial process is actually of coxal rather than sternal origin and probably represents partly fused coxal vesicles, but completely without the lateral coxal processes seen in other anthogonids. Also, one more point about structure of the posterior gonopods was omitted by Mršić. These are telopodal remnants located lateral to the medial process in both species (Fig. 9, $t$ ). Within the Anthogonidae, telopodal remnants are present in only two representatives of the Macrochaetosomatinae, and they are situated on the very robust lateral coxal processes (see Antic et al. 2015: 172, figs 77-78, 82-83). Generally, the posterior gonopods of biokoviellines are very reduced in size in comparison to the anterior gonopods or posterior gonopods of other anthogonids.

All the above-mentioned similarities between the genus Biokoviella and some representatives of Anthogonidae with respect to structure of the anterior gonopods argue in favor of including it in the indicated family, but on the other hand, structure of the posterior gonopods clearly separates the genus from all other anthogonids. We therefore think that inclusion of the subfamily Biokoviellinae as a member of Anthogonidae is justified.

Apart from features of the anterior and posterior gonopods, one more sexual character should be discussed. This character relates to the structure of leg pairs 3-7 in males. Mršić (1992: 54) stated that 
these pairs of legs "[...] are equipped with torsal papillae". He probably had in mind the tarsal papillae present in some chordeumatidans. In examining these pairs of legs in our specimens of both B. mauriesi and B. mosorensis sp. nov., we could not find any traces of tarsal papillae. Inasmuch as Mršić (1992) in the same paper dealt with the family Heterolatzeliidae, a small Dinaric group with tarsal papillae on leg pairs 3-7 in males, it seems likely that he may have accidentally mixed up the legs from specimens of these two groups. The absence of tarsal papillae in Biokoviella is one more reason for inclusion of this genus in the family Anthogonidae.

The family Anthogonidae now includes four subfamilies: Anthogoninae, Acherosomatinae, Biokoviellinae and Macrochaetosomatinae. All of these subfamilies are characterized by the presence of bristle apparatuses and/or bristle-clad pseudoflagella as parts of the anterior gonopods. On the other hand, they all possess some apomorphies that separate them from each other, and they would surely be recognized as separate families by some diplopodologist, a viewpoint to which we do not have any major objections. But in our opinion, it is better for now to leave four subfamilies within Anthogonidae and gradually reduce, if possible, the number of families within the extremely chaotic order Chordeumatida.

\section{Acknowledgments}

We are grateful to Roman Ozimec, Branko Jalžić, Marko Lukić, Jana Bedek, Alen Kirin, Petra Bregović, Robert Baković, Ratko Cvitanić, Martina Pavlek, Goran Rnjak, Slaven Nižetić and Hrvoje Cvitanović (all from Croatia); Teo Delić, Špela Borko \& Slavko Polak (all from Slovenia); Matija Petković (Serbia) and Michel Perreau (France) for collecting and making material considered in this study available to us. The authors would like to thank Miloš Bokorov (University Center for Electron Microscopy, Department of Biology and Ecology, University of Novi Sad, Serbia) for the SEM photographs. Helena Bilandžija (Croatia) lent us her wonderful photo of living Biokoviella mauriesi. Determinations of the accompanying fauna from Mt. Mosor caves were generously given by specialists for individual groups and we are sincerely grateful to them: P. Bregović and B. Jalžić for Coleoptera, M. Lukić for Collembola, M. Pavlek for Araneae and J. Bedek for Isopoda. The Biokovo Nature Park supported the collecting of diplopods and other forms of cave fauna through different projects. The team leader for most biospeleological research on Mt. Biokovo was R. Ozimec, and T.D. is extremely grateful to him for his enthusiasm in biospeleological research and for his support in the work on diplopod taxonomy. Dr. Henrik Enghoff and one anonymous referee provided helpful comments and suggestions on the manuscript. This study was partly supported by the Serbian Ministry of Education, Science and Technology (Grant No. 173038).

\section{References}

Antić D., Dražina T., Rađa T., Tomić V.T. \& Makarov S.E. 2015. Review of the family Anthogonidae (Diplopoda, Chordeumatida), with descriptions of three new species from the Balkan Peninsula. Zootaxa 3948 (2): 151-181. http://dx.doi.org/10.11646/zootaxa.3948.2.1

Bedek J., Gottstein Matočec S., Jalžić B., Ozimec R. \& Štamol V. 2006. Type locality catalogue of subterranean fauna in Croatia. Natura Croatica 15 (S1): 1-154.

Bedek J., Taiti S. \& Gottstein S. 2011. Catalogue and atlas of cave-dwelling terrestrial isopods (Crustacea: Oniscidea) from Croatia. Natura Croatica 20 (2): 237-354.

Enghoff H., Golovatch S., Short M., Stoev P. \& Wesener T. 2015. Diplopoda - Taxonomic overview. In: Minelli A. (ed.) The Myriapoda. Vol. 2. Treatise on Zoology - Anatomy, Taxonomy, Biology: 363-447. Brill, Leiden. http://dx.doi.org/10.1163/9789004188273 017 
Girometta U. 1914. Prilog poznavanju troglobijske i troglofilne faune Dalmacije uz geomorfološke bilješke o istraženim špiljama i jamama. Fauna Cavernarum Dalmatiae. Program Velike gimnazije u Spljetu za školsku godinu 1913/1914: 3-16.

Hoffman R.L. 1980. Classification of the Diplopoda. Muséum d'Histoire Naturelle, Genève.

Jalžić B., Bedek J., Bilandžija H., Bregović P., Čuković T., Ćukušić A., Cvitanović H., Dražina T., Đud L., Gottstein S., Hmura D., Kljaković Gašpić F., Komerički A., Kutleša P., Lukić M., Malenica M., Miculinić K., Ozimec R., Pavlek M., Raguž N., Slapnik R. \& Štamol V. 2013. The Cave Type Localities Atlas of Croatian Fauna. Volume 2. Croatian Biospeleological Society, Zagreb.

Jalžić B., Pavićević D., Nonveiller G. \& Rađa T. 1990. Novi podaci o špiljskim kornjašima (Insecta, Coleoptera) planine Mosor (Hrvatska). Speleologia Croatica 1: 31-34.

Makarov S.E., Ćurčić B.P.M., Tomić V.T., Rađa T., Rađa B., Ćurčić S.B., Mitić B.M. \& Lučić L.R. 2011. Revision of the family Heterolatzeliidae (Diplopoda, Chordeumatida). Zootaxa 2994: 33-44.

Mauriès J.-P. 1982. Une famille nouvelle et deux genres nouveaux de Cleidogonoidea, avec notes sur la classification de la superfamille (Diplopoda, Craspedosomida). Steenstrupia 8 (6): 165-176.

Mauriès J.-P. 1986. Un diplopode cavernicole relictuel des Alpes calcaires suisses: Niphatrogleuma wildbergeri n.g., n.sp. (Craspedosomida, Cleidogonoidea). Revue Suisse de Zoologie 93 (1): 249-256. Available from http://biodiversitylibrary.org/page/41278560 [accessed on 12 May 2016]

Mauriès J.-P. 1988. Un diplopode cavernicole cryophile relictuel du karst d'altitude des Pyrénées Centrales: Marboreuma brouquissei n.g., n.sp. (Craspedosomida, Cleidogonoidea). Bulletin de la Société d'Histoire naturelle de Toulouse 124: 29-34.

Mršić N. 1992. Biokoviella mauriesi gen. nov., sp. nov. (Biokoviellidae fam. nov.), Macrochaetosomatinae subf. nov. (Anthogonidae) and superfamily Cleidogonoidea of the western Balkans (Craspedosomidea, Diplopoda). Razprave IV. Razreda SAZU 33 (3): 51-91.

Mršić N. 1994. The Diplopoda (Myriapoda) of Croatia. Dvojnonoge (Diplopoda: Myriapoda) Hrvatske. Razprave IV. Razreda SAZU 35 (12): 219-296.

Pretner E. 1973. Koleopterološka fauna pećina i jama Hrvatske. Krš Jugoslavije 8: 101- 239.

Shear W.A. 2000. On the milliped family Heterochordeumatidae, with comments on the higher classification of the order Chordeumatida (Diplopoda). Invertebrate Taxonomy 14 (3): 363-376. http:// dx.doi.org/10.1071/IT99016

Shear W.A. 2011. Class Diplopoda de Blainville in Gervais, 1844. In: Zhang Z.-Q. (ed.) Animal biodiversity: An outline of higher-level classification and survey of taxonomic richness. Zootaxa 3148: $159-164$.

Shelley R.M. 2002. A revised, annotated, family-level classification of the Diplopoda. Arthropoda Selecta 11: 187-207.

Shelley R.M., Sierwald P., Kiser S.B. \& Golovatch S.I. 2000. Nomenclator generum et familiarum Diplopodorum II. A list of the genus and family-group names in the class Diplopoda from 1958 through 1999. Pensoft Publishers, Sofia.

Spelda J. 2001. Review of the millipede genus Pterygophorosoma Verhoeff, 1897 (Diplopoda, Chordeumatida, Craspedosomatidae). Andrias 15: 29-48.

Stoev P. 2001. On two myriapods (Chilopoda, Diplopoda) new to the fauna of Albania. Historia naturalis bulgarica 13: 109-110. Available from http://biodiversitylibrary.org/page/31191306 [accessed on 12 May 2016] 
Verhoeff K. 1899. Beiträge zur Kenntniss paläarktischer Myriopoden. VIII. Archiv für Naturgeschichte 65: 95-154. Available from http://biodiversitylibrary.org/page/15114916 [accessed 8 Jun. 2016]

Verhoeff K. 1930. Arthropoden aus südostalpinen Höhlen gesammelt von Karl Strasser. 3. Aufsatz: Acherosoma und seine verwandtschaftlichen Beziehungen. Mitteilungen über Höhlen- und Karstforschung 1: 1-12.

Manuscript received: 22 December 2015

Manuscript accepted: 24 February 2016

Published on: 17 June 2016

Topic editor: Rudy Jocqué

Desk editor: Kristiaan Hoedemakers

Printed versions of all papers are also deposited in the libraries of the institutes that are members of the EJT consortium: Muséum national d'Histoire naturelle, Paris, France; Botanic Garden Meise, Belgium; Royal Museum for Central Africa, Tervuren, Belgium; Natural History Museum, London, United Kingdom; Royal Belgian Institute of Natural Sciences, Brussels, Belgium; Natural History Museum of Denmark, Copenhagen, Denmark. 